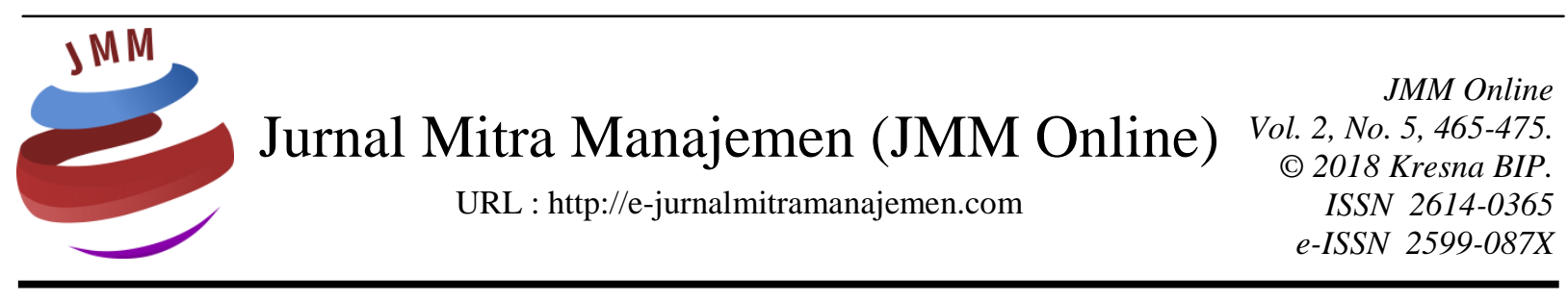

\title{
ANALISA PENGARUH TATA RUANG KANTOR TERHADAP KINERJA KARYAWAN DI BPRS SARANA PRIMA MANDIRI (SPM) PAMEKASAN MADURA
}

\author{
Didin Burhanuddin Rabbani ${ }^{1)}$, Syamsul Arifin ${ }^{2)}$

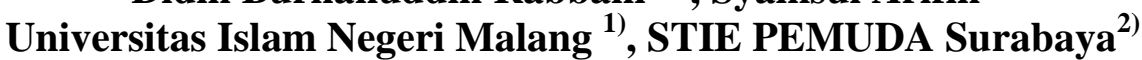

\section{INFORMASI ARTIKEL}

Dikirim : 01 September 2018

Revisi pertama : 06 September 2018

Diterima : 07 September 2018

Tersedia online : 28 September 2018

Kata Kunci : Tata Ruang Kantor, Kinerja Karyawan, BPRS

Email : aldinrabbani@gmail.com ${ }^{l)}$, syamsularifin556@gmail.com ${ }^{2)}$

\section{ABSTRAK}

Kinerja karyawan yang terus meningkat dan tata ruang kantor yang nyaman adalah bagian dari unsur-unsur manajemen tersebut, sehingga stigma positif perbankan syariah dapat mewabah pada masyarakat luas.

Tujuan dari penelitian ini adalah pertama: peneliti ingin mengetahui bagaimana keadaan tata ruang kantor pusat PT. BPRS Sarana Prima Mandiri (SPM) PamekasanMadura; kedua, peneliti ingin mengetahui analisa pengaruh tata ruang kantor terhadap kinerja karyawan di BPRS Sarana Prima Mandiri (SPM) Pamekasan Madura; ketiga, peneliti ingin mengetahui seberapa besar pengaruh tata ruang kantor terhadap kinerja karyawan di BPRS Sarana Prima Mandiri (SPM) Pamekasan Madura. Hasil penelitian menunjukkan bahwa terdapat pengaruh tata ruang kantor pusat PT. BPRS Sarana Prima Mandiri (SPM) Pamekasan Madura terhadap kinerja karyawannya. 


\section{PENDAHULUAN \\ Latar Belakang}

Perkembangan lembaga keuangan syariah, baik bank ataupun non bank semakin hari mengalami transformasi kearah yang lebih baik pada sistem lembaga keuangan di bumi pertiwi. Peranan lembaga keuangan syariah saat terjadinya krisis moneter pada tahun 1998 bukan semata-mata hanya menjadi alternatif namun telah menjadi salah satu solusi bagi negeri ini. Proses perkembangan lembaga keuangan syariah sendiri masih membutuhkan sosialisasi dan evaluasi dikalangan masyarakat luas. Dengan berdomisilinya mayoritas masyarakat muslim di Indonesia, secara kasat mata hal ini dapat menjadi salah satu pendukung bagi lembaga keuangan syariah untuk menerapkan sistem dan nilai ekonomi Islam untuk mewujudkan masyarakat makmur, sejahtera, dan berkeadilan, bukan hanya bagi umat muslim tetapi secara universal bagi penduduk negeri.

Dalam menerapkan segala hal berkenaan dengan terwujudnya dan meresapnya sistem dan nilai ekonomi Islam dalam lembaga keuangan syariah tidak lepas adanya faktor-faktor pendukung, terutama yang mencakup sumber daya manusia yang merupakan faktor pendukung utama yang perannya sangat penting. Dari segi manajemen sumber daya manusia terdapat pula manajemen organisasi yang harus dijalankan sehingga terhindar dari miss-management yang dapat menghambat berlangsungnya operasional lembaga keuangan syariah. Menurut Malayu s.p Hasibuan sebagaimana dikutip oleh Nashar menyatakan bahwa manajemen sumber daya manusia adalah "ilmu dan seni mengatur hubungan peranan tenaga kerja agar efektif dan efisien membantu tujuan perusahaan, karyawan dan masyarakat." Adapun fungsi manajemen sumber daya manusia terdiri dari perencanaan, pengorganisasian, pengarahan, pengendalian, pengadaan, pengembangan, kompensasi, pengintegrasian, pemeliharaan, dan pemberhentian. Tujuannya agar perusahaan mendapat rentabilitas laba yang lebih besar. Karyawan bertujuan memperoleh kepuasan dari pekerjaannya. Masyarakat bertujuan memperoleh barang atau jasa dengan harga wajar dan kompetitif di pasar, sedangkan pemerintah memperoleh pendapatan negara. Kemajuan suatu lembaga keuangan tidak terlepas dari peranan sumber daya manusia yang terlibat dalam suatu lembaga keuangan tersebut. Pengembangan sumber daya manusia atau karyawan sangatlah penting sehingga lembaga keuangan mampu bersaing secara sehat dengan lembaga keuangan lainnya baik dari faktor pelayanan ataupun promosi yang diberikan oleh lembaga keuangan.

Setelah peneliti melakukan observasi dan mengamati ruang kantor pusat PT. BPRS Sarana Prima Mandiri (SPM) Pamekasan, menurut hemat peneliti, tata ruang kantornya kurang menggunakan asas-asas tata ruang, terutama asas perubahan tempat kerja. Adapun asas-asas tata ruang yaitu asas jarak terpendek, asas rangkaian kerja, asas penggunaan segenap ruang, dan asas perubahan susunan tempat kerja. Peneliti melakukan wawancara dengan Bagian Funding yaitu Bapak Iqbal pada Jum'at malam, 8 Oktober 2015. Bapak Iqbal menyatakan bahwa karyawan di kantor pusat PT. BPRS Sarana Prima Mandiri (SPM) Pamekasan ini berjumlah 23 karyawan dan ada 5 karyawan dipindah ke kantor cabangnya di daerah Bandaran yang oleh peneliti juga dijadikan responden, jadi kesemuanya berjumlah 28 responden. Bapak Iqbal juga menambahkan bahwa selama dia bekerja yakni 2 tahun di kantor pusat PT. BPRS 
Sarana Prima Mandiri (SPM) belum ada perubahan yang signifikan berkenaan dengan tata ruang kantornya, selain itu juga kantor pusat PT. BPRS Sarana Prima Mandiri (SPM) Pamekasan yang berada di utara monumen Arek Lancor tersebut merupakan kantor induk (pusat) dari PT. BPRS Sarana Prima Mandiri yang kini memiliki kantor cabang sampai kota Bangkalan dan letak geografisnya berada di pusat perkotaan, sudah saatnya mendapat perhatian berkenaan dengan tata ruang kantor. Maka dari itu, peneliti tertarik untuk melakukan penelitian lebih lanjut di PT. BPRS Sarana Prima Mandiri (SPM) Pamekasan mengenai tata ruang kantor terhadap kinerja karyawan. Tata ruang kantor sangatlah penting demi keefektifan dan keefesienan proses kerja karyawan sehingga tercapai kepuasan kerja karyawan. Berdasarkan latar belakang tersebut, peneliti memutuskan untuk melakukan penelitian dengan judul "Pengaruh Tata Ruang Kantor Terhadap Kinerja Karyawan di Bank Pembiayan Rakyat Syariah Sarana Prima Mandiri (SPM) Pamekasan”.

\section{Rumusan Masalah}

Berdasarkan uraian latar belakang masalah diatas, maka penelitian ini memiliki rumusan masalah sebagaimana berikut:

1. Bagaimana penataan ruangan kantor pusat PT. BPRS Sarana Prima Mandiri (SPM) Pamekasan?.

2. Adakah pengaruh tata ruang kantor terhadap kinerja karyawan di BPRS Sarana Prima Mandiri (SPM) Pamekasan?.

3. Seberapa besar pengaruh tata ruang kantor terhadap kinerja karyawan di BPRS Sarana Prima Mandiri (SPM) Pamekasan?.

\section{Tujuan Penelitian}

Sehubungan dengan latar belakang masalah dan rumusan masalah, maka tujuan penelitian ini adalah:

1. Untuk mengetahui penataan ruangan kantor pusat PT. BPRS Sarana Prima Mandiri (SPM) Pamekasan.

2. Untuk mengetahui dan menganalisa adakah pengaruh tata ruang kantor terhadap kinerja karyawan di BPRS Sarana Prima Mandiri (SPM) Pamekasan.

3. Untuk mengetahui seberapa besar pengaruh tata ruang kantor terhadap kinerja karyawan di BPRS Sarana Prima Mandiri (SPM) Pamekasan.

\section{KAJIAN PUSTAKA}

Pada abad ke-21 ini ilmu rancang bangun berkembang sedemikian rupa, sehingga setiap organisasi memiliki banyak pilihan. Faktor-faktor yang mempengaruhi perkembangan tersebut selain berasal dari perkembangan tekhnologi, dan dipengaruhi oleh pasar bebas Asean yang dimulai pada akhir 2015 lalu yaitu program Masyarakat Ekonomi Asean (MEA), dimana masyarakat multikultural juga akan berkembang. Banyak tenaga kerja asing yang bekerja di Indonesia dan mereka juga memiliki selera dan persyaratan yang berbeda. Perkembangan desain arsitektur juga dipengaruhi oleh pola berpikir dan pola bekerja masyarakat terkait. Dengan demikian desain tata ruang perkantoran perlu benar-benar dirancang dengan seksama. Desain ruang di kantor Gubernur akan berbeda dengan desain kantor perpustakaan dan berbeda pula dengan 
tata ruang kantor lembaga keuangan atau perbankan yang sangat dibutuhkan bukan hanya oleh karyawan bank, tetapi juga bagi nasabah demi menjaga loyalitas dan perbankan memang bergelut dalam bidang usaha jasa.

Istilah Tata Ruang Kantor sendiri berasal dari bahasa Inggris, yaitu office layout atau sering disebut juga layout saja. Definisi yang menjelaskan tentang pengertian tata ruang kantor adalah suatu penyusunan perabotan dan perlengkapan pada luas lantai yang tersedia atau bisa juga diartikan sebagai penentuan kebutuhan ruang dan penggunaan secara rinci dari suatu ruang untuk menyiapkan suatu susunan praktis faktor-faktor fisik yang dianggap perlu bagi pelaksanaan kerja perkantoran dengan biaya yang layak, Laksmi (2009). Disisi lain, terdapat beberapa pertimbangan tata letak atau tata ruang kantor yang bersifat umum (beberapa pertimbangan dapat diterapkan pada suatu pabrik dan kantor). Pertimbangan ini berkaitan dengan kondisi kerja, kerjasama tim, otoritas, dan status. Terdapat pula dua kecenderungan utama dalam tata ruang kantor. Pertama, teknologi seperti telepon genggam, iPod, fax, internet, dan laptop menyebabkan tata ruang kantor semakin fleksibel dengan memindahkan informasi secara elektronis dan memudahkan karyawan bekerja diluar situs kerjanya. Kedua, perusahaan modern menciptakan kebutuhan dinamis akan ruang dan jasa. (Heizer \& Reinder : 2009).

\section{Pengertian Kinerja}

Kinerja SDM merupakan istilah yang berasal dari kata Job Performance atau Actual Performance (prestasi kerja atau prestasi sesungguhnya yang dicapai seseorang). Definisi kinerja karyawan yang dikemukakan Bambang Kusriyanto yang dikutip oleh Anwar Prabu Mangkunegara adalah "perbandingan hasil yang dicapai peran serta tenaga kerja persatuan waktu (lazimnya per jam)." Kinerja karyawan juga didefinisikan sebagai suatu hasil (prestasi) kerja secara kualitas dan kuantitas yang dicapai oleh seseorang karyawan dalam melaksnakan tugasnya sesuai dengan tanggung jawab yang diberikan kepadanya. Oleh karena itu dapat disimpulkan bahwa kinerja SDM adalah prestasi kerja atau hasil kerja (output) baik kualitas maupun kuantitas yang dicapai SDM persatuan periode waktu dalam melaksanakan tugas kerjanya sesuai dengan tanggung jawab yang diberikan kepadanya. Sedangkan menurut Hasibuan (2010) menyatakan bahwa kinerja adalah hasil kerja yang dapat dicapai oleh seseorang, kelompok atau organisasi sesuai dengan wewenang dan tanggung jawab masing-masing.

\section{Dasar Hukum Kinerja Karyawan (Tenaga Kerja)}

Karyawan atau tenaga kerja didefinisikan sebagai penduduk dalam usia kerja (working age population). Sedangkan pengertian karyawan atau tenaga kerja yang dimuat dalam Undang-Undang Nomor 13 Tahun 2003 tentang ketenagakerjaan dinyatakan bahwa tenaga kerja adalah orang yang mampu melakukan pekejaan guna menghasilkan barang atau jasa, baik untuk mememuhi kebutuhan sendiri maupun bersama. 


\section{Ruang Lingkup Manajemen Kinerja}

Manajemen kinerja adalah bagaimana tentang mengelola organisasi. Manajemen kinerja mengelola kinerja dalam konteks lingkungan bisnis baik internal maupun eksternal. Hal ini menyangkut bagaimana suatu usaha bisnis dikembangkan, apa yang ditetapkan untuk dilakukan dan bagaimana menjalankannya.Dengan demikian, cakupan manajemen kinerja meliputi kegiatan menganalisis tujuan unit kerja dan memastikan bahwa terdapat hubungan dengan tujuan menyeluruh organisasi, menganalisis keterampilan karyawan dan penugasan yang diberikan dalam kaitannyadengan tujuan unit kerja. Mengomunikasikan dengan jelas tujuan dan harapan kinerja setiap karyawan dan mendapatkan kesepakatan atas tujuan dan harapan tersebut, mengenal dan memperkenalkan kinerja baik dari setiap karyawan, mengenal dimana kinerja yang masih perlu diperbaiki dan memberikam dukungan yang diperlukan pekerja untuk memperbaiki kinerjanya (Wibowo: 2012).

\section{Pengertian BPRS}

Bank Pembiayaan Rakyat Syariah (BPRS) adalah bank syariah dalam kegiatannya tidak memberikan jasa dalam lalu lintas pembayaran (Pasal 1 angka 8). Bank Pembiayaan Rakyat Syariah tidak dapat dikonversi menjadi Bank Perkreditan Rakyat. Berbeda dengan Bank Umum Syariah, BPRS tidak diizinkan membuka kantor cabang, kantor pewakilan, dan jenis kantor lainnya di luar negeri. (Burhanuddin : 2010). Berdirinya BPRS di Indonesia selain didasari oleh tuntunan bermuamalah secara Islam yang merupakan keinginan kuat dari sebagian besar umat Islam di Indonesia, juga sebagai langkah aktif dalam rangka restrukturisasi perekonomian Indonesia yang dituangkan dalam berbagai paket kebijaksanaan keuangan, moneter, dan perbankan secara umum. Bank Syariah yang dalam kegiatannya tidak memberikan jasa dalam lalu lintas pembayaran. Bank Pembiayaan Rakyat Syariah (BPRS) tidak dapat dikonversi menjadi Bank Perkreditan Rakyat (BPR). Bank Pembiayaan Rakyat Syariah tidak diizinkan untuk membuka Kantor Cabang, kantor perwakilan, dan jenis kantor lainnya di luar negeri. Wibowo (2018).

\section{Larangan Bagi BPRS}

Larangan-larangan bagi BPRS tertuang dalam Pasal 25 UU Perbankan Syariah, yaitu sebagai beikut:

1) Melakukan kegiatan usaha yang bertentangan dengan Prinsip Syariah.

2) Menerima simpanan berupa Giro dan ikut serta dalam lalu lintas Melakukan kegiatan dalam valuta asing, kecuali penukaran uang asing dengan izin Bank Indonesia.

3) Melakukan kegiatan peransuransian, kecuali sebagai agen pemasaran pemasaran produk asuransi syariah.

4) Melakukan penyertaan modal, kecuali pada lembaga yang dibentuk untuk menanggulangi kesulitan likuiditas Bank Pembiayaan Rakyat Syariah.

5) Melakukan usaha lain diluar kegiatan usaha sebagaimana dimaksud dalam Pasal 21. (Anshori:2008). 


\section{METODELOGI PENELITIAN \\ Waktu dan Tempat Penelitian}

Tempat dan populasi dalam penelitian ini adalah seluruh karyawan bank pada PT. BPRS Sarana Prima Mandiri (SPM) Pamekasan di Jl. Agus Salim 20 Pamekasan dengan jumlah 23 karyawan dan 5 karyawan kantor kas Bandaran yang pernah bekerja di kantor pusatnya mulai dari karyawan operasional hingga manajerial. Sedangkan waktu dalam penelitian ini adalah bulan Januari-April 2016.

\section{Jenis Penelitian}

Penelitian ini menggunakan jenis pendekatan kuantitatif deskriptif yakni penelitian dengan menggunakan analisis data berupa angka-angka.

\section{Teknik Pengumpulan Data}

Instrumen penelitian yang digunakan untuk mengumpulkan data dalam penelitian ini adalah kuisioner (angket) dan dokumentasi, Pertama pada penelitian ini yang akan digunakan adalah angket tertutup dengan memberi tanda checklist $(\sqrt{ })$ dengan skala pemeringkatan $(5=$ Sangat Setuju, $4=$ Setuju, $3=$ Netral, $2=$ Tidak Setuju, 1 = Sangat Tidak Setuju) dan 2 butir kuisioner terbuka. Kuisioner diberikan kepada 28 karyawan PT. BPRS Sarana Prima Mandiri (SPM) Pamekasan. Dalam kuisioner tersebut telah disediakan pertanyaan dan responden memilih jawaban dengan cara memberikan tanda checklist $(\sqrt{ })$ dan menjawab 2 butir kuisioner terbuka. Kedua adalah dokumentasi yang merupakan data sekunder yang diperoleh dari berbagai sumber, baik dari literatur, artikel, data perusahaan dan lain-lain yang dianggap relevan dengan penelitian. Yang ketiga adalah Wawancara yang merupakan proses memperoleh keterangan atau data untuk tujuan penelitian dengan cara tanya jawab, sambil bertatap muka antara pewawancara dengan responden. Pada penelitian ini juga menggunakan via sms dan telepon.

\section{Teknis Analisi Data}

Teknik analisis data dalam penelitian ini menggunakan analisis regresi linear sederhana dengan program SPSS yaitu untuk meramalkan atau memprediksi pengaruh satu variabel bebas (X) terhadap variabel terikat (Y). Regresi sederhana dapat dianalisis karena didasari oleh hubungan fungsional atau hubungan sebab-akibat (kausal).

\section{HASIL DAN PEMBAHASAN \\ Deskripsi Responden}

Responden yang berjumlah 28 karyawan ini dianalisis berdasarkan karakteristik demografi. Hasil yang didapat dari analisis ini adalah mayoritas karyawan (responden) berjenis kelamin laki-laki dengan jumlah 18 karyawan $(64,3 \%)$, di bawah usia 30 tahun berjumlah 18 karyawan $(64,3 \%)$, berlatarbelakang pendidikan Sarjana (S1/S2/S3) berjumlah 24 karyawan $(85,7 \%)$, dan rata-rata lama bekerja diatas 3 tahun berjumlah 16 karyawan $(57,1 \%)$. 


\section{Uji Kualitas Data}

Uji validitas data penelitian ini menggunakan teknik korelasi product moment dan uji reliabilitas data menggunakan teknik alpha cronbach dengan program SPSS (Statistical Package for The Social Sciences) versi 18. Hasil pengujian menunjukkan bahwa kuesioner yang dibuat telah memenuhi standar yang validitas dengan nilai $\mathbf{r}_{\text {hitung }}$ masing-masing item pertanyaan di atas nilai $r_{\text {tabel }}$ yaitu 0,374 serta telah memenuhi standar yang reliabilitas dengan nilai alpha cronbach masing-masing variabel diatas 0,60 dengan taraf signifikansi $5 \%$.

\section{Uji Asumsi Klasik}

Penelitian ini juga dilakukan uji asumsi klasik yang digunakan untuk menganalisis data kuantitatif yang harus terbebas dari penyimpangan asumsi dasar atau untuk mengetahui model regresi yang digunakan pada penelitian ini termasuk layak atau tidak layak. Maka, sebelum dilakukan analisis regresi linier sederhana dilakukan pengujian asumsi klasik terlebih dahulu yang pada penelitian ini terdiri dari uji Normalitas, uji Heteroskedastisitas dan uji Autokorelasi. Berdasarkan hasil pengujian asumsi klasik dengan program SPSS (Statistical Package for The Social Sciences) versi 18, menunjukkan bahwa model persamaan analisis regresi linear yang dikembangkan dalam penelitian ini telah memenuhi asumsi klasik dan layak untuk digunakan sebagai alat analisis.

\section{Uji Hipotesis}

Hipotesis dalam penelitian ini adalah sebagai berikut:

Ho: tidak terdapat pengaruh tata ruang kantor terhadap kinerja karyawan di BPRS Sarana Prima Mandiri (SPM) Pamekasan Madura.

Ha: terdapat pengaruh tata ruang kantor terhadap kinerja karyawan di BPRS Sarana Prima Mandiri (SPM) Pamekasan Madura.

Berdasarkan pengujian hipotesis dengan Uji-t dapat diketahui bahwa nilai signifikansi dari variabel $\mathrm{X}$ (tata ruang kantor) adalah 0,000 dibawah 0,05 $(<0,05)$. Hal ini dapat disimpulkan dari tabel diatas bahwa kinerja karyawan PT. BPRS Sarana Prima Mandiri (SPM) Pamekasan Madura dipengaruhi oleh penataan ruang di kantor pusatnya.

Selain melihat dari nilai signifikansinya, dapat pula dilihat t hitungnya, dengan membandingkan $t_{\text {hitung }}$ dengan $t_{\text {tabel }}$. Sebagaimana tabel diatas $t$ hitung dari variabel $X$ (tata ruang kantor) adalah 5,471. Untuk dapat mengetahui besarnya $t$

tabel, yaitu dengan melihat $a=0,05$, jumlah sampel dikurangi banyaknya variabel bebas $(28-1=27)$, sehingga dapat diperoleh $\mathrm{t}$ tabelnya sebesar $1,703(\mathrm{t}$ hitung $=5,471>\mathrm{t}_{\text {tabel }}=1,703$ ), maka Ho ditolak dan Ha diterima. Sehingga dapat dikatakan bahwa terdapat pengaruh tata ruang kantor terhadap kinerja karyawan di BPRS Sarana Prima Mandiri (SPM) PamekasanMadura.

\section{Keadaan Penataan Ruang Kantor Pusat PT. BPRS Sarana Prima Mandiri (SPM) Pamekasan Madura}

Bagaimana keadaan penataan ruangan kantor pusat PT. BPRS Sarana Prima Mandiri (SPM) Pamekasan merupakan rumusan masalah yang pertama pada penelitian 
ini. Untuk menjawab rumusan masalah pertama ini, selain dengan pengamatan langsung ke objek penelitian, peneliti juga menggunakan 2 item kuisioner terbuka, yakni bagaimana keadaan ruangan kantor dan bagaimana keinginan/saran para responden (karyawan) berkenaan dengan tata ruang kantornya agar tercipta suasana kerja yang nyaman, efektif, dan efisien.

Penataan ruang kantor pusat yang diinginkan oleh para karyawan (responden) agar tercipta suasana kerja yang nyaman, efektif, dan efisien dapat disimpulkan dari jawaban item pertanyaan ke dua pada kuisioner terbuka yang berhasil dikumpulkan sebagai berikut:

a. Agar lebih diperhatikan mengenai akses kerja karyawan terutama sedikit pelebaran pada lorong kantor.

b. Ruangan kantor agar diperluas atau direnovasi karena merupakan kantor pusat agar nyaman dalam bekerja.

c. Ruangan tetap dibuat bersih, harum, dan wangi karena kebersihan merupakan sebagian dari iman.

d. Adanya perlengkapan kantor yang memadai, baik untuk kelancaran, kenyamanan, dan keamanan kerja.

e. Ditambah camilan yang terkondisikan dalam bekerja (ramah lingkungan kerja) agar mengurangi kejenuhan dan stres dalam bekerja.

f. Dapat pula ditambah dengan hiasan ruangan seperti gambar panorama dan lainnya sehingga suasana ruangan terasa lebih hidup.

Selanjutnya, kalau pembahasan rumusan masalah yang pertama diatas menurut sudung pandang para karyawan (responden), kali ini dilihat dari sudut pandang teoritis sebagaimana tertulis pada kajian teori (Bab II) bahwa jenis penataan ruang kantor pusat PT. BPRS Sarana Prima Mandiri (SPM) Pamekasan adalah tata ruang kantor terbuka (lihat denah kantor pada halaman 5). Jadi, di lembaga perbankan syariah ini menerapkan penataan ruang kantor terbuka, tidak dipisahkan dengan adanya sekatsekat (pedengan-pedengan) diantara meja kerja karyawan dalam satu ruangan. Ruang besar terbuka adalah lebih baik daripada ruang yang sama luasnya tetapi terbagi dalam satuan-satuan kecil. Tata ruang kantor terbuka lebih memuaskan daripada terpisahpisah atau tata ruang kantor tertutup, karena :

a. Memungkinkan pengawasan yang lebih efektif terhadap segenap pegawai.

b. Lebih memudahkan hubungan diantara para pegawai, menumbuhkan rasa persatuan yang lebih erat.

c. Lebih memudahkan tersebarnya cahaya dan peredaran cahaya.

d. Jika terjadi penambahan pegawai atau alat-alat kantor, tata ruang terbuka lebih mudah menampungnya.

e. Mudah untuk mengadakan hubungan langsung, penyeragaman kerja, dan pembagian peralatan kerja.

f. Biaya lebih hemat atau murah untuk pemeliharaan ruangan kerja, penggunaan kelengkapan ruangan dan peralatan, penggunaan telepon dan lain-lainnya.

Adapun resiko kerugian menggunakan tata ruang kantor terbuka adalah:

a. Apabila terjadi kegaduhan atau kebisingan efeknya akan cepat meluas.

b. Pegawai yang membutuhkan konsentrasi tinggi akan terganggu jika terjadi kebisingan. 
c. Kemungkinan nampak adanya tumpukan-tumpukan berkas atau kertas dan peralatan kerja lainnya, sehingga mengakibatkan pemandangan yang kurang baik.

\section{Pengaruh Tata Ruang Kantor terhadap kinerja karyawan di BPRS Sarana Prima Mandiri (SPM) Pamekasan Madura}

Berdasarkan hasil analisis regresi linear sederhana dengan program SPSS versi 18 diperoleh koefisien variabel independen tata ruang kantor $(X)=0,534$ dan konstanta (a) sebesar 8,759, sehingga model persamaan regresi yang diperoleh dalam penelitian ini adalah sebagai berikut:

$\mathrm{Y}=8,759+0,534 \mathrm{X}$

Dari model persamaan regresi linear sederhana di atas dapat diinterpretasikan sebagai berikut:

a. Konstanta (a) sebesar 8,759, dimana nilai konstanta kinerja karyawan sebesar 8,759 menunjukkan bahwa jika variabel X (tata ruang kantor) sama dengan nol (tidak dipertimbangkan), maka kinerja karyawan adalah sebesar 8,759 satuan.

b. Koefisien variabel independen (b) $=0,534$, dapat diartikan bahwa besarnya koefisien variabel tata ruang kantor bertanda positif $(0,534)$ mengindikasikan bahwa jika tata ruang kantor naik 1 satuan, maka skor kinerja karyawan akan naik sebesar 0,534 satuan.

Berdasarkan hasil koefisien regresi diatas, variabel independen yang bernilai positif dapat diartikan bahwa tata ruang kantor mempunyai hubungan yang positif terhadap kinerja karyawan di BPRS Sarana Prima Mandiri (SPM) Pamekasan Madura. Oleh karena itu, BPRS Sarana Prima Mandiri(SPM) harus senantiasa selalu memelihara dan meningkatkan penataan ruangan kantornya, sehingga karyawan di BPRS Sarana Prima Mandiri (SPM) Pamekasan dapat bekerja dengan efektif, efisien, dan memperoleh kenyaman dalam bekerja.

\section{Persentase Pengaruh Tata Ruang Kantor Terhadap Kinerja Karyawan PT. BPRS Sarana Prima Mandiri (SPM) Pamekasan Madura}

Persentase pengaruh tata ruang kantor terhadap kinerja karyawan di BPRS Sarana Prima Mandiri (SPM) Pamekasan dapat diketahui dengan melakukan analisi data dengan persamaan regresi linear sederhana sebagaimana dijelaskan di atas.

Uji koefisien korelasi (r) yang bertujuan untuk mengetahui hubungan antara variabel independen (tata ruang kantor) dan variabel dependen (kinerja karyawan) yang dilakukan sebelum mengetahui koefisien determinasi $\left(\mathrm{R}^{2}\right)$. Berdasarkan pengujian koefisien korelasi (r) dengan program SPSS versi 18, dapat diketahui bahwa nilai koefisien korelasi (r) yaitu dengan melihat pada kolom $\mathrm{R}$ sebesar 0,732. Hal ini berarti bahwa keeratan hubungan antara tata ruang kantor dan kinerja karyawan di BPRS Sarana Prima Mandiri (SPM) Pamekasan adalah kuat.

Selanjutnya dengan mengetahui koefisien korelasi (r), maka dapat diketahui seberapa besar pengaruh variabel independen (tata ruang kantor) terhadap variabel dependen (kinerja karyawan) dengan program SPSS versi 18 dengan melihat besarnya $\mathrm{R}$ Square yaitu 0,535 atau 53,5\% yang berarti bahwa variabel independen (tata ruang kantor) mampu menjelaskan variabel dependen (kinerja karyawan) sebesar 53,5\%. Sedangkan sisanya $(100 \%-53,5 \%=46,5 \%)$ dipengaruhi oleh variabel-variabel 
lainnya yang tidak diperhitungkan dalam analisis penelitian ini.Kontribusi penataan ruang kantor sebesar 53,5\%, dapat dikatakan cukup tinggi, dengan demikian PT. BPRS Sarana Prima Mandiri (SPM) Pamekasan harus selalu memberikan suasana dan inovasi baru pada penataan ruangan kantornya, melihat nilai kontribusi faktor lain seperti halnya kompensasi, bonus, promosi, mutasi, dan motivasi kerja yang masih cukup tinggi yaitu $46,5 \%$.

\section{KESIMPULAN DAN SARAN Kesimpulan}

Penataan ruang kantor pusat PT. BPRS Sarana Prima Mandiri (SPM) Pamekasan sebagaimana pernyataan responden dari kuisioner terbuka sudah sesuai dengan harapan para karyawan. Tata ruang kantor yang ada pada kantor pusat PT. BPRS Sarana Prima Mandiri (SPM) Pamekasan adalah jenis tata ruang kantor terbuka, dimana dalam suatu ruangan tidak dipisahkan dengan sekat-sekat (pedenganpedengan) diantara meja karyawan. Tata ruang kantor terbuka juga lebih murah pada pembiayaan kantor dan pemeliharaannya dan serta mudah dalam melakukan pengawasan kerja karyawan.

Terdapat pengaruh yang signifikan dari penataan ruang kantor pusat PT, BPRS Sarana Prima Mandiri (SPM) Pamekasan terhadap kinerja karyawannya, terbukti dengan melihat hasil Uji-t bahwa nilai signifikansi dari variabel $\mathrm{X}$ (tata ruang kantor) adalah 0,000 dibawah 0,05 $(<0,05)$ dan dapat pula dilihat $\mathrm{t}$ hitungnya, dengan membandingkan $t_{\text {hitung }}$ dengan $t_{\text {tabel. }}$. Sebagaimana tabel diatas $t$ hitung dari variabel $X$ (tata ruang kantor) adalah 5,471. Untuk dapat mengetahui besarnya t tabel, yaitu dengan melihat $a=0,05$, jumlah sampel dikurangi banyaknya variabel bebas $(28-1=$ 27), sehingga dapat diperoleh $\mathrm{t}$ tabelnya sebesar $1,703\left(\mathrm{t}_{\text {hitung }}=5,471>\mathrm{t}_{\text {tabel }}=1,703\right)$, maka Ho ditolak dan Ha diterima. Sehingga dapat dikatakan bahwa terdapat pengaruh tata ruang kantor terhadap kinerja karyawan di BPRS Sarana Prima Mandiri (SPM) Pamekasan.Begitu pula dengan melihat hasil koefisien korelasi (r) dengan hasil 0,732, hal ini berarti antara tata ruang kantor dan kinerja karyawan memiliki keeratan hubungan yang kuat. Selain itu pula, dengan melihat hasil koefisen determinasi $\left(\mathrm{R}^{2}\right)$ pada kolom $\mathrm{R}$ Square sebesar 0,535, artinya bahwa pengaruh tata ruang kantor terhadap kinerja karyawan PT. BPRS Sarana Prima Mandiri (SPM) Pamekasan adalah sebesar 53,5\%. Sedangkan dilihat dari hasil analisis regresi sederhana $(Y=a+b X)$ yaitu $\mathrm{Y}=8,759+0,534 \mathrm{X}$, dimana nilai konstanta (a) kinerja karyawan sebesar 8,759 menunjukkan bahwa jika variabel tata ruang kantor sama dengan nol (tidak dipertimbangkan), maka kinerja karyawan adalah sebesar 8,759 satuan dan $b=0,534$, dapat diartikan bahwa besarnya koefisien variabel kinerja karyawan bertanda positif $(0,534)$ mengindikasikan bahwa jika tata ruang kantor naik 1 satuan, maka skor kinerja karyawan akan naik sebesar 0,534 satuan.

\section{Saran}

Berdasarkan hasil penelitian yang telah dipaparkan di atas, maka selanjutnya peneliti menyampaikan saran-saran yang kiranya dapat bermanfaat kepada pihak-pihak yang terkait atas hasil penelitian ini. Adapun saran-saran tersebut selain dari peneliti juga merupakan hasil pendapat karyawan, untuk saran kepada pihak PT. BPRS Sarana 
Prima Mandiri (SPM) Pamekasan diharapkan dapat mempertahankan dan meningkatkan kualitas seni penataan ruangan kantor sehingga memberikan feedback bagi karyawan dan perusahaan yaitu dapat meningkatnya kinerja karyawan yang tentunya akan menguntungkan semua pihak bank syariah ini, baik dari komisaris hingga para nasabah. Untuk dapat meningkatkan kualitas penataan ruang kantornya, para karyawan memberikan inovasi berupa saran diantaranya dengan dilakukannya pelebaran lorong kantor, perluasan ruangan, ruangan dibuat harum, dapat pula ditambah camilan yang terkondisikan (ramah lingkungan kerja) untuk mengurangi stress kerja agar tercipta suasana kerja yang nyaman, efektif, dan efisien. Saran-saran tersebut benar adanya karena dari hasil analisis data menunjukkan bahwa pengaruh tata ruang kantor terhadap kinerja karyawan cukup tinggi. Sehingga dengan adanya inovasi penataan ruang kantor, nanntinya pengaruhnya terhadap kinerja karyawan semakin meningkat. Sedangkan bagi peneliti selanjutnya diharapkan tidak hanya menguji dua variabel saja yaitu tata ruang kantor terhadap kinerja karyawan, sangat baik bila ditambah dengan variabel lain seperti kompensasi, bonus, promosi, mutasi dan motivasi.

\section{DAFTAR PUSTAKA}

Abdul Ghofur Anshori. 2008. Penerapan Prinsip Syari'ah dalam Lembaga Pembiyaan dan perusahaan Pembiyaan. Yogyakarta: Pustaka Belajar.

Dokumen PT. BPRS. 2008. Sarana Prima Mandiri Pamekasan. Feasibility Study. Surabaya: Rafa Consulting,

Ghazali,Imam. 2011. Aplikasi Analisis Multivariate dengan Program IBM SPSS 19. Semarang: Badan Penerbit Universitas Diponegoro.

Heizer, Jay dan Barry Render. 2009. Manajemen Operasi Buku 1 Edisi 9. Jakarta: Salemba Empat.

Hasibuan. 2010. Manajemen Sumber Daya Manusia Jakarta: Bumi Aksara.

Kaswan. 2012. Manajemen Sumber Daya Manusia Untuk Keunggulan Bersaing Organisasi. Yogyakarta: Graha Ilmu,

Laksmi dkk. 2009. Manajemen Perkantoran Modern. Jakarta: Penaku,

Nashar. 2014. Manajemen Sumber Daya Manusia. Surabaya: Pena Salsabila,

Ridwan dan Sunarto. 2013. Pengantar Statistika untuk Penelitian: Pendidikan, Sosial, Ekonomi dan Bisnis. Bandung: Alfabeta,

Sugiyono. 2010. Metode Penelitian Kuantitatif Kualitatif $R \&$ D. Bandung: Alfabeta, Sujarweni, V. Wiratna dan Poly Endrayanto. 2012. Statistika Untuk Penelitian. Yogyakarta: Graha Ilmu,

Sukoco, Badri Munir. 2007. Manajemen Administrasi Perkantoran Modern. Jakarta: Erlangga.

Undang Nomor 13 Tahun 2003 tentang ketenagakerjaan Republik Indonesia

Wibowo. Manajemen Kinerja. Jakarta: Rajawali Pers,

Wibowo. 2018. Pengertian Bank Pembiayaan Rakyat Syariah (BPRS). Jakarta: Airlangga. 